Sains Malaysiana 50(10)(2021): 3095-3106

http://doi.org/10.17576/jsm-2021-5010-22

\title{
Hypocholesterolemic Effect of Acacia and Citrus Honeys on Cholesterol Induced Sprague Dawley Rats
}

(Kesan Hipokolesterolemik Madu Akasia dan Sitrus pada Tikus Sprague Dawley Sprague Teraruh Kolesterol)

\author{
Muhammad Bilal Hussain, Rabia Shabir Ahmad*, Muhammad Umair Arshad, Ali Imran \& Muhammad \\ IMRAN
}

\begin{abstract}
During the last decade, scientific investigations have put more focus on diet based therapies to prevent numerous maladies especially hypercholesterolemia and related disorders. Current project was designed to discover the nutraceutical worth of natural unifloral honeys from Acacia nilotica (Desi Kikar) and Citrus limetta (Mosambi) against hypercholesterolemia. Initially both honey varieties were analyzed for TPC and TFC, followed by DPPH and FRAP assays. Afterwards, honey drinks were prepared using different concentrations of Acacia and Citrus honeys (10:20:30 $\mathrm{g} / 250 \mathrm{~mL}$ water) and were tested in experimental rat model. Initially the rats were provided with high cholesterol diet (2\%) to induce hypercholesterolemia, which were then provided with honey drinks for 8 weeks. These were monitored regularly for feed and water intake and weekly for body weight gain. The blood samples for total cholesterol, LDL, HDL, triglyceride levels as well as safety assessment tests were analyzed at the intervals of 0, 28, and 56 days, which showed that Acacia honey was better in terms of antioxidant potential (DPPH, FRAP, and TPC) than the Citrus honey. Feed and drink intakes along with body weight gain showed significant effect among all the experimental groups. Substantial reduction in cholesterol, LDL and triglycerides was observed in $G_{3}(213.82 \pm 3.36$ to $183.95 \pm 3.02 \mathrm{mg} / \mathrm{dL}$ ), $(150.05 \pm 2.30$ to $125.44 \pm 3.32 \mathrm{mg} / \mathrm{dL})$ and $(163.24 \pm 4.87$ to $133.64 \pm 4.75 \mathrm{mg} / \mathrm{dL})$, respectively, from 0 to $56^{\text {th }}$ day. Liver and kidney functioning values decreased within the normal range. Owing to strong antioxidant potential, Acacia honey was proved to be more effective in controlling hypercholesterolemia than the Citrus honey.
\end{abstract}

Keywords: Acacia honey; antioxidants; Citrus honey; hypercholesterolemia

ABSTRAK

Sepanjang dekad yang lalu, penyelidikan saintifik lebih tertumpu pada terapi berasaskan diet untuk mencegah banyak penyakit terutama hiperkolesterolemia dan gangguan yang berkaitan. Projek ini dirancang untuk mengkaji nilai nutraseutikal madu unifloral semula jadi daripada Acacia nilotica (Desi Kikar) dan Citrus limetta (Mosambi) terhadap hiperkolesterolemia. Pada mulanya kedua-dua varieti madu dianalisis untuk TPC dan TFC, diikuti dengan asai DPPH dan FRAP. Selepas itu, minuman madu disediakan menggunakan kepekatan yang berbeza daripada madu Akasia dan Sitrus (10:20:30 g/250 mL air) dan diuji dalam model tikus uji kaji. Pada mulanya tikus diberi diet tinggi kolesterol (2\%) untuk mengaruh hiperkolesterolemia, yang kemudian diberikan minuman madu selama 8 minggu. Ia dipantau secara berkala untuk pengambilan makanan dan air dan setiap minggu untuk kenaikan berat badan. Sampel darah untuk kadar kolesterol jumlah, LDL, HDL, aras trigliserida serta ujian penilaian keselamatan dianalisis pada selang 0, 28 dan 56 hari yang menunjukkan bahawa madu Akasia lebih baik daripada segi potensi antioksidan (DPPH, FRAP dan TPC) daripada madu Sitrus. Pengambilan makanan dan minuman bersama dengan kenaikan berat badan menunjukkan kesan yang signifikan antara semua kumpulan uji kaji. Pengurangan kolesterol, LDL dan trigliserida yang ketara diperhatikan pada $G_{3}(213.82 \pm 3.36$ hingga $183.95 \pm 3.02 \mathrm{mg} / \mathrm{dL}),(150.05 \pm 2.30 \mathrm{hingga} 125.44 \pm 3.32$ $\mathrm{mg} / \mathrm{dL}$ ) dan (163.24 \pm 4.87 hingga $133.64 \pm 4.75 \mathrm{mg} / \mathrm{dL})$, masing-masing dari 0 hingga hari ke-56. Nilai fungsi hati dan ginjal menurun dalam julat normal. Oleh kerana potensi antioksidan yang kuat, madu Akasia terbukti lebih berkesan dalam mengawal hiperkolesterolemia daripada madu Sitrus.

Kata kunci: Antioksidan; hiperkolesterolemia; madu Akasia; madu Sitrus 


\section{INTRODUCTION}

Hypercholesterolemia refers to the excess of cholesterol in the bloodstream of humans, which could cause narrowing down or blockage of arteries, thus slowing or stopping the constant blood flow to the vital organs of body, especially towards brain and heart (Ballantyne et al. 2018). It has been stated that the hypercholesterolemia could be a risk factor for the onset of atherosclerosis, thrombosis, ischemic stroke, and cardiovascular diseases (Shiroma \& Lee 2010).

Cardiovascular diseases (CVDs) are the group of maladies, which mainly relate to heart or blood vessels and principally cover myocardial infarction (heart attack). During last few decades, it has become a common health problem for the masses around the globe especially in middle and low income countries (Hajar 2016). During the year 2016, approximately 17.9 million individuals expired owing to cardiovascular diseases and till 2030 this rate will increase up to 23.4 million (Laslett et al. 2012; WHO 2018). There are several contributing factors which are enhancing the spread of this malady including smoking, diabetes, high cholesterol, sedentary life style, obesity, and family history (Tiffe et al. 2017).

Numerous medicinal therapies have been developed to counter this life threatening disease, but with the increase in public awareness towards nutrition, people are putting more emphasis on having organic way of treatment and by using effective and safe natural products that can hinder the scavenging activities of free radicals, which could in turn provide protection to the masses against it. In the recent era, contrary to the synthetic products, deterrence of myocardial infarction has been principally associated with the intake of fresh food materials and antioxidant rich plants due to their higher efficacy and safety. Among these foods, natural honey holds a strong position (Mendis et al. 2011).

Honey is a viscous, sweet and nutritionally dense food product having carbohydrates, amino acids, flavonoids, phenolic compounds, aromatic substances, organic acids, vitamins, minerals, and enzymes. It is prepared by the honey bees in their especially designed stomachs, by sucking the nectar through their tube like tongue, either from single plant source (unifloral honey) or from numerous flowering plants (multifloral honey), which can be stored in bee hives for further ripening (Ahmad et al. 2017). It has been estimated that honey contains about 200 beneficial constituents in it that could play a therapeutic role in CVDs, with especial reference to its antioxidant potential. Main antioxidant constituents of honey are phenolics, flavonoids, ascorbic acid, $\alpha$-tocopherol, certain enzymes (catalase, glucose oxidase), and beta-carotene (Alvarez-Suarez et al. 2014). Being nutritionally diverse, honey helps to perform various clinical and biologically significant functions in human beings including anti-cancer, antimicrobial, wound healing, anti-inflammatory, aid fertility complications and also act as anti-hyperlipidemic and cardio-protective agent (Rao et al. 2016). Honey could be obtained from number of useful plant sources during their flowering seasons; among them Acacia nilotica (Desi Kikar) and Citrus limetta (Mosambi) hold a key spot, owing to the presence of numerous chemical constituents, including phenolic acids, flavonoids, carotenoids, tannins, terpenoids, alkaloids, kaempferol, oleosins, resins, terpenes, essential, and volatile oils (Ali et al. 2012), which are helpful in performing various pharmacological functions including antioxidant, antifungal, anti-hypertensive, anti-cancer, anti-asthamatic, antiulcer, anti-diabetic, antimicrobial with especial reference to cure hypercholesterolemic activities (Ali et al. 2012; Chaudhari et al. 2016). This research work is mainly designed to investigate the cholesterol lowering effect of both honeys acquired from these plants by feed model trial.

\section{MATERIALS AND Methods}

PROCUREMENT OF RAW MATERIAL

The honey samples (Acacia nilotica and Citrus limetta) were procured from National Agricultural Research Center (NARC), Islamabad, Pakistan. These were transported in air-tight jars to the Department of Food Science, Nutrition and Home Economics, Institute of Home and Food Sciences, Government College University, Faisalabad. Each sample was packed in glass bottle of $1000 \mathrm{~g}$ capacity. None of samples exceeded the storage period of three months. All honey samples were stored at $4{ }^{\circ} \mathrm{C}$ and before analysis kept overnight at $25 \pm 2{ }^{\circ} \mathrm{C}$.

\section{PREPARATION OF HONEY EXTRACT}

Methanolic extract of honey was prepared by adding 25 $\mathrm{mL}$ of methanol $(99 \%)$ and $7.5 \mathrm{~g}$ of honey in $50 \mathrm{~mL}$ falcon tube. This mixture was uninterruptedly stirred at room temperature; with a shaker (Tecnal TE-420, Brazil) for the period of $24 \mathrm{~h}$. In this method, filter paper was used to remove particles. The final volume of the solution was adjusted by the addition of $25 \mathrm{~mL}$ of methanol (Ruiz-Ruiz et al. 2017). This methanolic extract was then used in the determination of TPCs, TFCs, FRAP and DPPH assays. 


\section{ANTIOXIDANT POTENTIAL}

TOTAL PHENOLIC CONTENTS

Total phenolic contents of both types of honey were analyzed by Folin-Ciocalteu reagent, using the protocol of Singleton et al. (1999) with few modifications. 0.5 $\mathrm{mL}$ of the honey solution was mixed with $2.5 \mathrm{~mL}$ of Folin-Ciocalteau reagent $(2 \mathrm{~N})$ and incubated at $25{ }^{\circ} \mathrm{C}$ for about $5 \mathrm{~min}$. Afterwards, $2 \mathrm{~mL}$ of $\mathrm{Na}_{2} \mathrm{CO}_{3}$ solution $(75 \mathrm{~g} / \mathrm{L})$ was added into the honey solution and again incubated for $2 \mathrm{~h}$ at the temperature of $25^{\circ} \mathrm{C}$. Following the incubation, the absorbance of the honey solution was measured at $765 \mathrm{~nm}$ by UV-Visible spectrophotometer (Perkin-Elmer Lambda 25, Waltham, MA, USA). The standard chemical used for calibration for (curve preparation was the Gallic acid $(0-1000 \mathrm{mg} / \mathrm{L})$. It was expressed as milligram (mg) of gallic acid equivalent (GAE) in gram of honey.

\section{TOTAL FLAVONOID CONTENTS}

The TFCs of Acacia and Citrus honeys were analyzed by the method of Isla et al. (2011) with minor changes. $0.5 \mathrm{~mL}$ of honey solution $(0.1 \mathrm{~g} / \mathrm{mL})$ was mixed with 5 $\mathrm{mL}$ of $2 \% \mathrm{AlCl}_{3}$. It was then incubated for $10 \mathrm{~min}$ at 25 ${ }^{\circ} \mathrm{C}$ resultantly forming a flavonoid- aluminium complex. The absorbance of complex was measured at $415 \mathrm{~nm}$ with the help of UV-Visible spectrophotometer. The standard chemical used for calibration for curve preparation was Rutin (0-100 mg/L). It was expressed as milligram of rutin equivalent (RE) in gram of honey. Ferric reducing antioxidant power (FRAP) assay The FRAP assay of honey samples was measured in accordance with the method used by Benzie and Strain (1996) with few modifications. This method was based on the principle of reducing ferric 2, 4, 6-tripyridyl-s-triazine complex (Fe3+-TPTZ) to its colored ferrous form (Fe2+-TPTZ), in the presence of antioxidants. The reagent was formed by adding $2.5 \mathrm{~mL}$ of $10 \mathrm{mM}$ TPTZ (2,4,6-tripyridyls-triazine) solution into $40 \mathrm{mM} \mathrm{HCl}, 25 \mathrm{~mL}$ of $0.3 \mathrm{M}$ acetate buffer and $2.5 \mathrm{~mL}$ of $20 \mathrm{mM} \mathrm{FeCl}_{3}$ at $\mathrm{pH}$ value of 3.6. One gram of honey sample was dissolved well in $10 \mathrm{~mL}$ of $\mathrm{n}$-hexane-acetone mixture $(6: 4)$. It was then filtered through filter paper of Whatman \#4. An aliquot of $200 \mathrm{~mL}$ of the honey solution was mixed with $1.8 \mathrm{~mL}$ of FRAP (Ferric Reducing Antioxidant Power) reagent, which is then incubated for $10 \mathrm{~min}$ and absorbance was measured at wavelength of $593 \mathrm{~nm}$. For the calibration curve preparation, Trolox was used and the acquired results were expressed as milligram of Trolox equivalent (TE) per 100 gram of honey.

\section{FREE RADICAL SCAVENGING ACTIVITY (DPPH)}

Free radical scavenging activity (FRSA) was determined by 1,1- Diphenyl- 2 -Picryl hydrazyl (DPPH) assay as reported by Isla et al. (2011), with slight changes. The $20 \mathrm{mg} / \mathrm{L}$ of the DPPH solution was formed by mixing 2 $\mathrm{mg}$ of DPPH in $100 \mathrm{~mL}$ of methanol. About $0.75 \mathrm{~mL}$ of the methanolic honey solution was added to $1.5 \mathrm{~mL}$ of DPPH solution. It was followed by its incubation at 25 ${ }^{\circ} \mathrm{C}$ for $15 \mathrm{~min}$ and then the absorbance was measured at $517 \mathrm{~nm}$ by using UV-Visible spectrophotometer. In this method, Ascorbic acid was taken as a standard. The concentration of honey sample required to scavenge $50 \%$ of DPPH $\left(\mathrm{EC}_{50}\right)$ was measured based on the ascorbic acid calibration curve $(0-10 \mathrm{mg} / \mathrm{L})$.

\section{EXPERIMENTAL ANIMALS}

Seventy adult male Sprague Dawley (SD) rats having average weight 191.04 grams were acquired from the National Institute of Health, Islamabad, Pakistan, after taking approval from Institution of Animal Ethics Committee (IAEC). These were kept in stainless steel wire bottom cages at the temperature of $25 \pm 2{ }^{\circ} \mathrm{C}$ with the relative humidity of $60 \pm 5 \%$ with $12 \mathrm{~h}$ lightdark cycle, in environmentally controlled animal house of College of Pharmacology, Faculty of Science and Technology, Government College University, Faisalabad Pakistan. Freshly prepared basal diet was served to the rats having $65 \%$ starch, $10 \%$ corn oil, $10 \%$ casein, $10 \%$ cellulose, $4 \%$ mixture of salt, $1 \%$ mixture of vitamins for the period of one week along with distilled water that fulfill their needs for growing ad libitum.

\section{ANIMAL GROUPS AND EXPERIMENTAL DESIGN}

Seventy male Sprague Dawley rats were distributed into seven groups having ten subjects each. Few rats were sacrificed at the start of trial to get the baseline values of the selected traits. Feed containing 2\% cholesterol was given to the experimental rats to induce hypercholesterolemia in them. Afterwards, all the groups were supplied with honey drinks, except the control group $\left(G_{0}\right)$ which was supplied with simple water. Groups $\mathrm{G}_{1}, \mathrm{G}_{2}$, and $\mathrm{G}_{3}$ were provided with $10 \mathrm{~g}, 20 \mathrm{~g}$ and $30 \mathrm{~g}$ of Acacia honey $/ 250 \mathrm{~mL}$, respectively, while the Citrus honey was given to groups $\mathrm{G}_{4}(10 \mathrm{~g}), \mathrm{G}_{5}(20 \mathrm{~g})$ and $\mathrm{G}_{6}(30 \mathrm{~g})$ per $250 \mathrm{~mL}$ of water.

\section{FEED AND DRINK INTAKE}

To determine the effect of experimental diet on the subjects, the net feed intake of each rat was calculated on 
daily basis, by excluding left-over and collected spilled diet during the entire study period. Honey drink was also given to the rats of different treatment groups in graduated drinking bottles of $250 \mathrm{~mL}$ each, in accordance with the study plan. The drink consumption was also measured on daily basis.

\section{BODY WEIGHT GAIN}

All through the experimental period, increase in body weight of rats of each group was measured on weekly basis to determine the effect of diet on their body weights by using electronic weighing balance (KERN 440-35 N).

\section{COLLECTION OF SERUM OF RATS}

For the serum collection, overnight fasted Sprague Dawley rats were killed by using, $0.4 \mathrm{~mL}$ of urethane anesthesia (25\%)/100 g of body weight. Afterwards, the blood of subjects was collected by cardiac puncture. In accordance with standard protocol, the blood was allowed to stand at room temperature for around 30 min. Then serum was separated from it by the use of centrifugation process, through the centrifuge machine (LABCENT 5000), by operating it at $3000 \mathrm{rpm}$ for the period of 15 min (Uchida et al. 2001).

\section{SERUM LIPID PROFILE}

Serum total cholesterol level was analyzed by the CHODPAP method (Stockbridge et al. 1989). High density lipoproteins (HDLs) were measured by HDL Cholesterol Precipitant method and low density lipoproteins (LDL) in serum samples were determined by following the procedure of McNamara et al. (1990). Total triglycerides were analyzed by liquid triglycerides (GPO-PAP) method (Annoni et al. 1982).

\section{LIVER AND KIDNEY FUNCTIONING TESTS}

Liver functioning tests including ALT (alanine transferase) and AST (aspartate transferase) were determined by (DNPH-method) using Sigma Kits and ALP (alkaline phosphatase) was executed by adopting the alkaline phosphates (DGKC- method) (Basuny et al. 2009). Kidney functioning tests comprising Serum urea (GLDH-method) and creatinine (Jaffe-method) values were documented to evaluate the renal functionality of variant experimental groups (Kumari et al. 2017).

\section{STATISTICAL ANALYSIS}

All samples were analyzed and descriptive data demonstration is shown as means with standard deviations. Differences between groups were assessed by analysis of variance (ANOVA) for data with groups using Statistix version 8.1. software. LSD was used to determine the level of significance between the mean values of the experimental groups. The significance level was $5 \%$ for all the tests.

\section{RESULTS AND DISCUSSION}

ANTIOXIDANT POTENTIAL

The honey samples (Acacia nilotica and Citrus limetta) were characterized for TPC, TFC, FRAP and DPPH values, respectively. The results of these parameters indicated that the both types of honey varieties possessed strong antioxidant potential. The TPC (56.31 mg GAE/g), FRAP (593.25 $\mu \mathrm{mol} / 100 \mathrm{~g})$ and DPPH (81.4\%) values was found higher in variety Acacia. The variety Citrus showed lower values for these parameters which were $11.21 \mathrm{mg} \mathrm{GAE} / \mathrm{g}, 390.62 \mu \mathrm{mol} / 100 \mathrm{~g}$ and $55.14 \%$ for TPC, FRAP and DPPH, respectively. The results also reported that, the Citrus variety samples have higher TFC contents $(5.05 \mathrm{mg} \mathrm{RE} / \mathrm{g}$ ) as compared to TFC contents (4.63 mg RE/g) present in Acacia variety. The similar results have been reported in previous studies (Hussain et al. 2019). The different varieties of honey possessed strong profile of TFC, TPC, flavonoids, phenols, antioxidants and other biological active compounds (Ahmed et al. 2016). Overall, the results of present study with respect to antioxidant potential indicate that the Acacia variety is better than Citrus honey variety.

\section{FEED AND DRINK INTAKE}

Mean values for feed and drink intake in different groups of rats (per rat/day) have been shown graphically (Figures $1 \& 2$ ). The results indicated that the honey drink aided in the reduction of feed intake by the subjects, owing to the presence of high amount of natural sugar in it, in contrast to the control group, which resulted in decrease of body weight. The highest feed intake (33.83 g/rat/ day) was observed in $\mathrm{G}_{0}$ (control group) followed by $\mathrm{G}_{4}(30.96 \mathrm{~g} / \mathrm{rat} /$ day $)$ and $\mathrm{G}_{1}(29.07 \mathrm{~g} / \mathrm{rat} /$ day $)$. Lowest value of feed intake was observed in $\mathrm{G}_{3}(25.93 \mathrm{~g} / \mathrm{rat} /$ day) followed by $\mathrm{G}_{6}(27.85 \mathrm{~g} / \mathrm{rat} / \mathrm{day})$. Means belonging to the drink intake of subjects of all study groups (Figure 2) showed that there was an increase in honey drink intake throughout the study period, thus presenting suitability of product. Maximum value was observed in $\mathrm{G}_{3}(32.95 \mathrm{~mL} / \mathrm{rat} /$ day $)$ followed by $\mathrm{G}_{6}(32.72 \mathrm{~mL} /$ rat/day), while the minimum value was observed in $\mathrm{G}_{1}$ (32.48 $\mathrm{mL} / \mathrm{rat} /$ day) and $\mathrm{G}_{4}(32.38 \mathrm{~mL} / \mathrm{rat} /$ day) (Samat et al. 2014). 


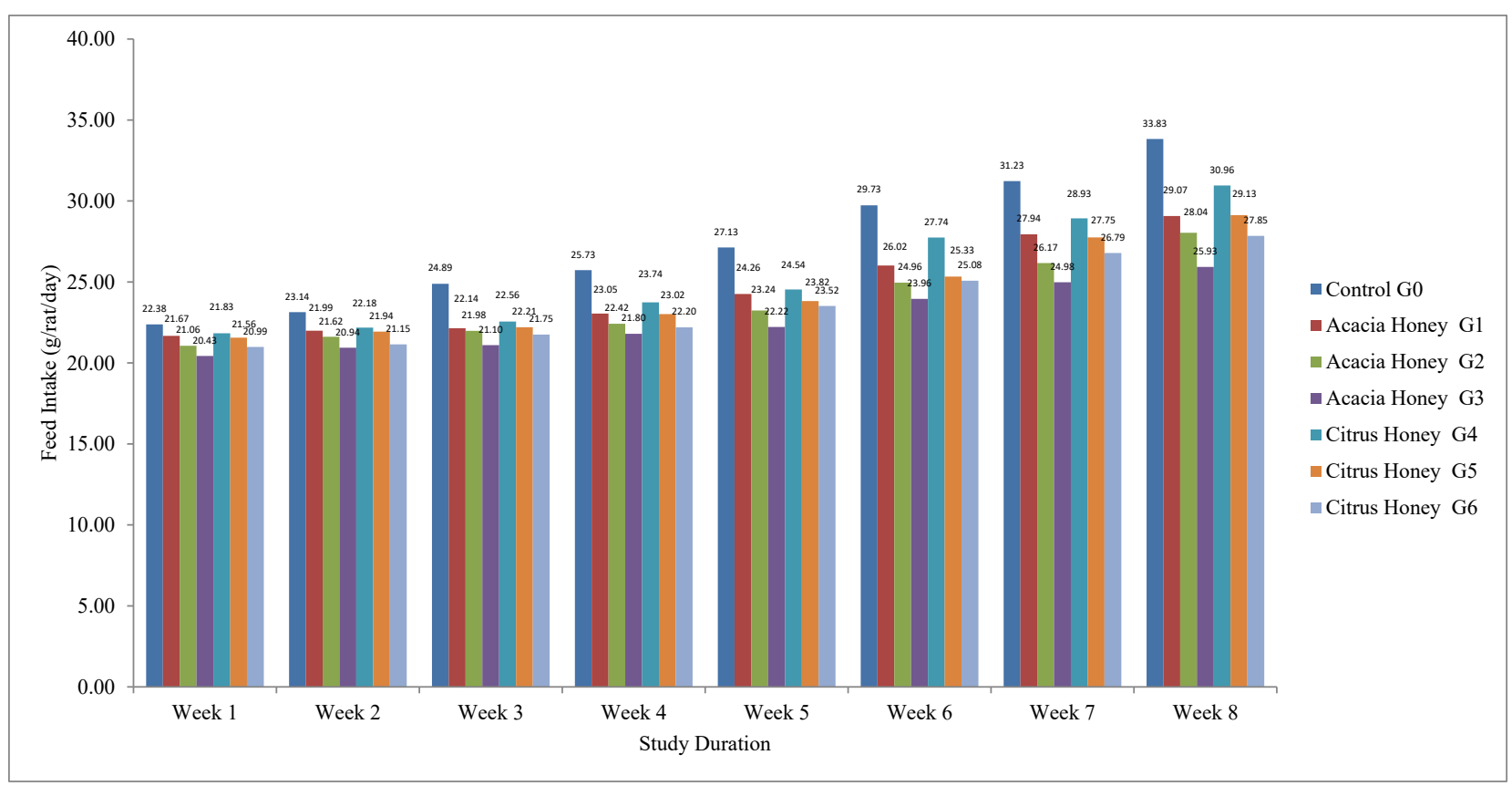

FIGURE 1. Effect of Acacia and Citrus Honeys on feed intake of hypercholesterolemic rats during 08 weeks



FIGURE 2. Effect of Acacia and Citrus Honeys on honey drink intake of hypercholesterolemic rats during 08 weeks

\section{BODY WEIGHT GAIN}

With reference to body weight gain shown in Figure 3 , the subjects of control group $\left(\mathrm{G}_{0}\right)$ showed maximum value in the 8 th week of study (265.96 g) followed by $\mathrm{G}_{1}(250.86 \mathrm{~g})$ and $\mathrm{G}_{4}(255.13 \mathrm{~g})$. On the other hand, minimum body weight was analyzed in the subjects of $\mathrm{G}_{3}(226.91 \mathrm{~g})$ in the last week of study followed by $\mathrm{G}_{6}(239.70 \mathrm{~g})$. The researchers have found two possible 
reasons for the body weight reduction in the honey fed subjects, first one is the high concentration of antioxidants especially the flavonoids, and secondly the lower glycemic index of honey, which allow it to digest, absorbed and metabolized at slower rate, causing a slower rise in blood glucose, which indirectly help in weight loss by reducing the appetite of subjects (Nemoseck et al. 2011). Another possible reason in this scenario could be presence of hydrogen peroxide in the honey, which acts as a powerful insulin mimetic agent, produced by the oxidation of glucose by glucose oxidase enzyme (Samat et al. 2017).

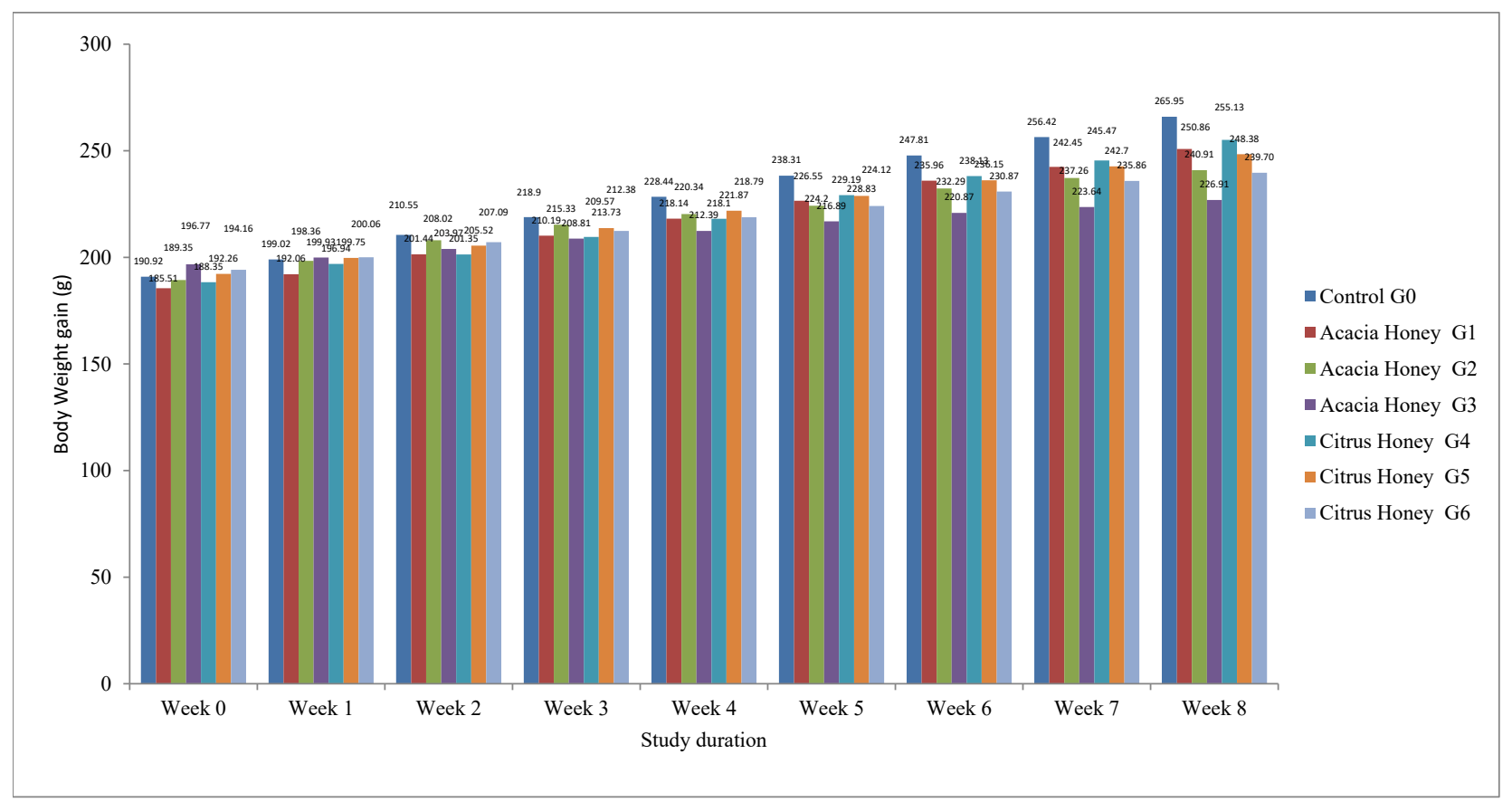

FIGURE 3. Effect of Acacia and Citrus Honeys on body weight gain of hypercholesterolemic rats during 08 weeks

\section{TOTAL CHOLESTEROL}

It is obvious from the mean values as depicted in Table 1, that there was non-significant $(>0.05)$ effect observed in control group $\left(\mathrm{G}_{0}\right)$, while all other experimental groups showed significant decreasing results. Among all the groups, $\mathrm{G}_{3}$ (30 g Acacia honey) was proved to be the most effective one, as it showed maximum reduction in the total cholesterol level of the rats from $213.82 \pm 3.36$ $\mathrm{mg} / \mathrm{dL}$ to $183.95 \pm 3.02 \mathrm{mg} / \mathrm{dL}$ on 56 th day of study. The work of Adnan et al. (2011) was aligned with the current investigation, in which hypercholesterolemic rats were supplied with Acacia honey for 60 days. Afterwards, the reduction was observed in the concerned parameter, which concluded that because of higher total phenolic contents than the citrus, Acacia honey has the potential to reduce the cholesterol level. Another study, conducted by Majid et al. (2013), in which 70 young healthy adults received natural honey for 4 weeks. At the end of trial, decline was observed in the total cholesterol level of subjects of experimental group as compared with the group receiving no honey. The prime factor in total cholesterol reduction by the honey was owing to its strong antioxidant potential. Numerous other factors that may have an effect on antioxidant activity of honey include the botanical origin, soil type, seasonal and environmental factors, geographical conditions as well as its processing (Kıvrak \& Kıvrak 2017).

\section{LOW DENSITY LIPOPROTEINS (LDL)}

It is evident from the results as given in Table 1, that maximum reduction in LDL level was observed in $\mathrm{G}_{3}(125.44 \pm 3.32 \mathrm{mg} / \mathrm{dL})$ on 56 th day of trial period, followed by $\mathrm{G}_{6}(133.18 \pm 4.50 \mathrm{mg} / \mathrm{dL})$. On the other hand, minimum reduction was analyzed among the 
subjects of group $\mathrm{G}_{1}(133.36 \pm 4.84 \mathrm{mg} / \mathrm{dL})$ and $\mathrm{G}_{4}$ $(135.40 \pm 3.24 \mathrm{mg} / \mathrm{dL})$, who have taken $10 \mathrm{~g}$ of Acacia and Citrus honey, respectively. Münstedt et al. (2009) also found the same declining pattern in the LDL level of hypercholesterolemic subjects, which were supplied with pure honey solution for two weeks, in comparison with the subjects receiving same amount of sugar solution. The main reason for the LDL reduction in the hypercholesterolemic subjects by the ingestion of honey was found to be not only its strong antioxidant potential but also owing to its ability in weight reduction, which could resultantly lessen the level of bad cholesterol in subjects (Nemoseck et al. 2011).

TABLE 1. Effect of different unifloral honeys on serum lipid profile

\begin{tabular}{|c|c|c|c|c|}
\hline \multirow[b]{2}{*}{ Biochemical parameters } & \multirow[b]{2}{*}{ Treatment } & \multicolumn{3}{|c|}{ Study duration } \\
\hline & & 0 Day & $28^{\text {th }}$ Day & $56^{\text {th }}$ Day \\
\hline \multirow{2}{*}{ Total cholesterol (mg/dL) } & G0 & $206.51 \pm 4.28^{\mathrm{Da}}$ & $206.50 \pm 4.26^{\mathrm{BCa}}$ & $206.48 \pm 4.28^{\mathrm{Aa}}$ \\
\hline & G1 & $210.43 \pm 5.17^{\mathrm{CDa}}$ & $207.81 \pm 4.75^{\mathrm{ABa}}$ & $199.30 \pm 4.21^{\mathrm{BCb}}$ \\
\hline \multirow{11}{*}{ LDL (mg/dL) } & $\mathrm{G} 2$ & $215.48 \pm 6.58^{\mathrm{ABa}}$ & $209.90 \pm 4.90^{\mathrm{ABb}}$ & $194.93 \pm 3.49^{\mathrm{Dc}}$ \\
\hline & G3 & $213.82 \pm 3.36^{\mathrm{BCa}}$ & $201.92 \pm 2.62^{\mathrm{Db}}$ & $183.95 \pm 3.02^{\mathrm{Fc}}$ \\
\hline & G4 & $207.26 \pm 2.96^{\mathrm{Da}}$ & $204.06 \pm 2.33^{\mathrm{CDb}}$ & $200.02 \pm 3.18^{\mathrm{Bc}}$ \\
\hline & G5 & $218.88 \pm 4.33^{\mathrm{Aa}}$ & $210.10 \pm 4.40^{\mathrm{Ab}}$ & $196.10 \pm 4.41^{\mathrm{CDc}}$ \\
\hline & G6 & $215.00 \pm 4.93^{\mathrm{ABa}}$ & $203.32 \pm 3.35^{\mathrm{CDb}}$ & $188.83 \pm 4.13^{\mathrm{Ec}}$ \\
\hline & G0 & $148.69 \pm 3.61^{\mathrm{Ea}}$ & $148.64 \pm 3.64^{\mathrm{Aa}}$ & $148.66 \pm 3.62^{\mathrm{Aa}}$ \\
\hline & G1 & $152.75 \pm 5.46^{\mathrm{CDa}}$ & $143.24 \pm 2.54^{\mathrm{Cb}}$ & $133.36 \pm 4.84^{\mathrm{Cc}}$ \\
\hline & $\mathrm{G} 2$ & $156.24 \pm 3.77^{\mathrm{BCa}}$ & $146.27 \pm 2.47^{\mathrm{ABb}}$ & $129.01 \pm 2.61^{\mathrm{Dc}}$ \\
\hline & G3 & $150.05 \pm 2.30^{\mathrm{DEa}}$ & $140.21 \pm 1.93^{\mathrm{Db}}$ & $125.44 \pm 3.32^{\mathrm{Ec}}$ \\
\hline & G4 & $154.22 \pm 5.86^{\mathrm{Ca}}$ & $145.56 \pm 2.86^{\mathrm{BCb}}$ & $135.40 \pm 3.24^{\mathrm{BCc}}$ \\
\hline & G5 & $161.01 \pm 3.45^{\mathrm{Aa}}$ & $148.80 \pm 2.64^{\mathrm{Ab}}$ & $137.11 \pm 3.47^{\mathrm{Bc}}$ \\
\hline \multirow{4}{*}{ HDL (mg/dL) } & G6 & $158.39 \pm 2.76^{\mathrm{ABa}}$ & $147.25 \pm 4.54^{\mathrm{ABb}}$ & $133.18 \pm 4.50^{\mathrm{Cc}}$ \\
\hline & $\mathrm{G}_{0}$ & $35.18 \pm 2.10^{\mathrm{ABa}}$ & $35.20 \pm 2.11^{\mathrm{DEa}}$ & $35.19 \pm 2.09^{\mathrm{Ea}}$ \\
\hline & G1 & $33.44 \pm 2.87^{\mathrm{BCc}}$ & $37.04 \pm 2.10^{\mathrm{CDb}}$ & $41.14 \pm 2.14^{\mathrm{Da}}$ \\
\hline & $\mathrm{G} 2$ & $30.00 \pm 2.67^{\mathrm{DEc}}$ & $41.30 \pm 3.30^{\mathrm{Bb}}$ & $44.40 \pm 3.50^{\mathrm{Ca}}$ \\
\hline \multirow{11}{*}{ Triglycerides (mg/dL) } & G3 & $36.09 \pm 2.55^{\mathrm{Ac}}$ & $45.29 \pm 2.89^{\mathrm{Ab}}$ & $54.09 \pm 3.34^{\mathrm{Aa}}$ \\
\hline & G4 & $29.49 \pm 2.81^{\mathrm{Ec}}$ & $34.39 \pm 2.93^{\mathrm{Eb}}$ & $40.69 \pm 2.61^{\mathrm{Da}}$ \\
\hline & G5 & $32.37 \pm 3.89^{\mathrm{CDc}}$ & $36.47 \pm 2.87^{\mathrm{Deb}}$ & $42.29 \pm 3.61^{\mathrm{CD}}$ \\
\hline & G6 & $34.44 \pm 2.75^{\mathrm{ABCc}}$ & $39.14 \pm 2.27^{\mathrm{BCb}}$ & $48.84 \pm 3.89^{\mathrm{Ba}}$ \\
\hline & G0 & $156.25 \pm 3.18^{\mathrm{Ea}}$ & $156.19 \pm 3.18^{\mathrm{BCa}}$ & $156.16 \pm 3.18^{\mathrm{Aa}}$ \\
\hline & $\mathrm{G}_{1}$ & $160.07 \pm 3.57^{\mathrm{CDa}}$ & $157.06 \pm 3.93^{\mathrm{BCa}}$ & $149.66 \pm 4.18^{\mathrm{Bb}}$ \\
\hline & $\mathrm{G}_{2}$ & $165.07 \pm 4.12^{\mathrm{Aba}}$ & $159.57 \pm 2.43^{\mathrm{ABb}}$ & $144.47 \pm 4.38^{\mathrm{CDc}}$ \\
\hline & G3 & $163.24 \pm 4.87^{\mathrm{BCa}}$ & $150.04 \pm 4.64^{\mathrm{Db}}$ & $133.64 \pm 4.75^{\mathrm{Ec}}$ \\
\hline & G4 & $157.84 \pm 3.90^{\mathrm{DEa}}$ & $154.35 \pm 4.08^{\mathrm{Cb}}$ & $150.15 \pm 3.15^{\mathrm{Bc}}$ \\
\hline & G5 & $167.44 \pm 4.46^{\mathrm{Aa}}$ & $160.94 \pm 4.82^{\mathrm{Ab}}$ & $146.84 \pm 4.39^{\mathrm{BCc}}$ \\
\hline & G6 & $164.80 \pm 4.15^{\mathrm{ABa}}$ & $153.86 \pm 4.91^{\mathrm{Cb}}$ & $140.86 \pm 4.69^{\mathrm{Dc}}$ \\
\hline
\end{tabular}

Means with different lower case letters $(\mathrm{a}, \mathrm{b}, \mathrm{c})$ are statistically different $(\mathrm{p}<0.05)$ from $0-56^{\text {th }}$ day. Means with different upper case letters $(\mathrm{A}$, B, C) are statistically different $(\mathrm{p}<0.05)$ within control and all other hypercholesterolemic groups 


\section{HIGH DENSITY LIPOPROTEINS (HDL)}

HDL, also known as good cholesterol is a factor which needs to be increased in the blood of healthy subjects. It is clear from the mean values as mentioned in Table 1 , that a non-significant effect was observed in $G_{0}$. An increasing trend was observed in HDL level of rats as the intake of both the honeys was increased. Maximum HDL value was observed in $\mathrm{G}_{3}(54.09 \pm 3.34 \mathrm{mg} / \mathrm{dL})$ on 56th day of trial, while minimum value was exhibited by $\mathrm{G}_{4}(40.69 \pm 2.61 \mathrm{mg} / \mathrm{dL})$, which were taking $10 \mathrm{~g}$ of Citrus honey. As the Acacia honey was having higher antioxidant potential, it exerted relatively strong positive impact on the HDL level of subjects rather than the citrus honey. In a relevant study conducted by Alagwu et al. (2011), the rats were provided with $1 \mathrm{~mL}$ of honey/10 $\mathrm{mL}$ of drinking water for 22 weeks on daily basis. The analysis of their blood showed a significant increase in HDL, which relates to the fact that the honey could increase good cholesterol level in the subjects.

\section{TRIGLYCERIDES}

As the study progressed, the value of triglycerides as depicted in Table 1 was decreased among the groups of Acacia honey $\left(G_{1}\right.$ to $\left.G_{3}\right)$ and Citrus honey $\left(G_{4}\right.$ to $\left.G_{6}\right)$ as compared to control group $\mathrm{G}_{0}$. This reduction was more pronounced amongst the subjects of $\mathrm{G}_{3}$ i.e. from $163.24 \pm 4.87 \mathrm{mg} / \mathrm{dL}$ to $133.64 \pm 4.75 \mathrm{mg} / \mathrm{dL}$ than all other groups. However, minimum reduction was observed in $\mathrm{G}_{4}$ from $157.84 \pm 3.90 \mathrm{mg} / \mathrm{dL}$ to $150.15 \pm 3.15 \mathrm{mg} / \mathrm{dL}$. Mohammadimanesh et al. (2019) analyzed a drop in the triglyceride level of diabetes mellitus (DM) male Wister rats by the use of variant honeys including Acacia honey. The rats were provided with honey at $1 \mathrm{mg} / \mathrm{kg}$ body weight, by oral gavage for 10 weeks. At the end of trial, it was concluded that the triglyceride level of rats was reduced at quick rate. One of the possible reasons in this regard may be due to the hypotriglyceridemic effect of fructooligosaccharides (FOS), or some other carbohydrates such as isomaltulose. These are degraded in the colon by microflora, instead of hydrolyzing in the small intestine, which results in the production of short-chain fatty acids and a different colonic microflora, which could impart useful impact on lipid metabolism (Mussatto \& Mancilha 2007).

\section{LIVER FUNCTIONING TESTS}

Liver functioning tests including alanine transaminase (ALT), aspartate transaminase (AST), and alkaline phosphatase (ALP), as shown in Table 2 were carried out to determine the normal functionality of liver of the concerned subjects. It is clear from the mean values that a significant effect was observed on the AST value of the groups receiving honey $\left(\mathrm{G}_{1}-\mathrm{G}_{6}\right)$ in comparison with the control one. Maximum decrease was observed in the AST level of $\mathrm{G}_{3}$ from $184.31 \pm 3.00 \mathrm{IU} / \mathrm{L}$ to $148.07 \pm 4.27$ $\mathrm{IU} / \mathrm{L}$ on 56 th day of study, followed by $\mathrm{G}_{6}$. Minimum reduction was analyzed in the subjects of $\mathrm{G}_{4}$, from $187.51 \pm 3.42 \mathrm{IU} / \mathrm{L}$ to $164.92 \pm 4.39 \mathrm{IU} / \mathrm{L}$. The mean values from Table 2 showed a significant impact of honey on the ALT level of subjects. Acacia honey was found to be more effective in lowering ALT value of rats than the Citrus honey, being provided at same concentration. Among all the groups, minimum value was observed in $\mathrm{G}_{3}(38.92 \pm 3.62 \mathrm{IU} / \mathrm{L})$. Least effective concentration of honey was found to be given to the groups $G_{1}$ and $G_{4}$, which had ALT level of $45.84 \pm 2.77 \mathrm{IU} / \mathrm{L}$ and $45.66 \pm 2.55$ $\mathrm{IU} / \mathrm{L}$. Results regarding ALP value, it followed the same pattern as aforementioned parameters, in which $\mathrm{G}_{3}$ exhibited maximum decreasing trend as compared to all other experimental groups.

Similar results were observed in a study conducted by Afroz et al. (2014), in which Male Wister rats were supplied with Sundarban honey $(5 \mathrm{~g} / \mathrm{kg})$ for 4 weeks, which aided them to neutralize the effects of APAP (N-acetyl-para-aminophenol)-induced acute hepatic and renal damage. In the same manner, Tanvir et al. (2015), treated female Wister rats with natural honey, which helped them in controlling hepatotoxicity and oxidative damage caused by induction of chlorpyrifos (CPF), in contrast to the subjects which faced degenerative necrosis, congestion, inflammation in the liver and edema, owing to the absence of honey intake. Additionally, liver protective effects of honey were supported by the work of El-Haskoury et al. (2018) and Fihri et al. (2016).

\section{KIDNEY FUNCTIONING TESTS}

Kidney functioning tests (urea and creatinine) were also carried out to assess the effects of functional honey drinks on the kidneys of subjects. With reference to urea, it is clear from the mean values (Table 3 ) that a non-significant effect was observed in control group $\left(\mathrm{G}_{0}\right)$. Contrary to it, the subjects of $\mathrm{G}_{3}$ showed a significant response towards the reduction in urea level, which was decreased to $25.95 \pm 3.55 \mathrm{mg} / \mathrm{dL}$ from the initial value of $33.15 \pm 4.36$ $\mathrm{mg} / \mathrm{dL}$. Minimum reduction of concerned parameter was analyzed in $\mathrm{G}_{1}(36.02 \pm 3.04 \mathrm{mg} / \mathrm{dL})$ and $\mathrm{G}_{4}(34.07 \pm 4.24$ $\mathrm{mg} / \mathrm{dL}$ ). It is clear from the mean values (Table 3 ) that creatinine level of the rats was decreased significantly as the concentration of honey intake was increased in the drink form. In $\mathrm{G}_{3}$ subjects, the initial value of concerned parameter was decreased from $1.07 \pm 0.04 \mathrm{mg} / \mathrm{dL}$ to 
$0.80 \pm 0.06 \mathrm{mg} / \mathrm{dL}$. Minimum reduction of creatinine was observed in the $\mathrm{G}_{1}(0.88 \pm 0.03 \mathrm{mg} / \mathrm{dL})$ and $\mathrm{G}_{4}(0.92 \pm 0.05$ $\mathrm{mg} / \mathrm{dL}$ ), which were taking $10 \mathrm{~g}$ of Acacia and Citrus honey throughout the study period.

Allied results were acquired by Achuba and Nwokogba (2015), in which chemoprotective and ameliorative effects of natural honey were studied on Wistar albino rats in which nephro-and hepatoxocity was induced by kerosene and gasoline, which led to the conclusion that intake of honey diet, had protective effect against the damage caused to the liver and kidney of subjects. Likewise, Abdel-Moneim and Ghafeer (2007), conducted a research to analyze the effects of natural honey on kidneys by cadmium, and it was concluded that owing to strong antioxidant potential, honey was able to neutralize the cadmium-induced hepatotoxicity and nephrotoxicity.

TABLE 2. Effect of different unifloral honeys on liver function tests

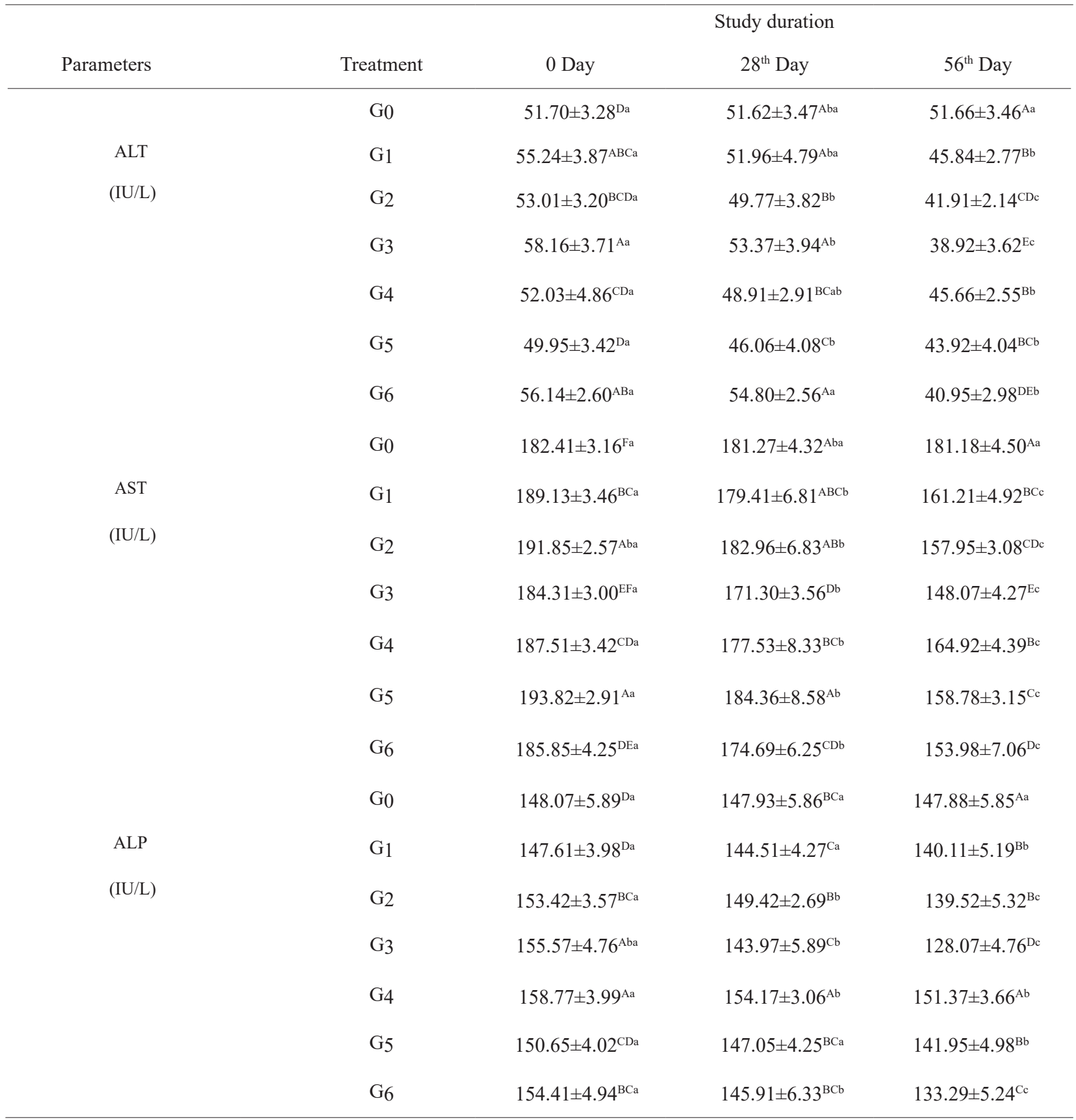

Means with different lower case letters $(a, b, c)$ are statistically different $(\mathrm{p}<0.05)$ from $0-56^{\text {th }}$ day. Means with different upper case letters $(A, B$, C) are statistically different $(\mathrm{p}<0.05)$ within control and all other hypercholesterolemic groups 
Allied results were acquired by Achuba and Nwokogba (2015), in which chemoprotective and ameliorative effects of natural honey were studied on Wistar albino rats in which nephro-and hepatoxocity was induced by kerosene and gasoline, which led to the conclusion that intake of honey diet, had protective effect against the damage caused to the liver and kidney of subjects. Likewise, Abdel-Moneim and Ghafeer (2007), conducted a research to analyze the effects of natural honey on kidneys by cadmium, and it was concluded that owing to strong antioxidant potential, honey was able to neutralize the cadmium-induced hepatotoxicity and nephrotoxicity.

TABLE 3. Effect of different unifloral honeys on kidney function tests

\begin{tabular}{|c|c|c|c|c|}
\hline \multirow[b]{2}{*}{ Parameters } & \multicolumn{4}{|c|}{ Study duration } \\
\hline & Treatment & 0 Day & $28^{\text {th }}$ Day & $56^{\text {th }}$ Day \\
\hline & $\mathrm{G}_{0}$ & $35.42 \pm 3.81^{\mathrm{BCDa}}$ & $35.21 \pm 3.83^{\mathrm{Aba}}$ & $35.15 \pm 3.85^{\mathrm{Aba}}$ \\
\hline Urea & $\mathrm{G}_{1}$ & $38.51 \pm 3.65^{\mathrm{Aba}}$ & $36.21 \pm 3.44^{\mathrm{Aa}}$ & $36.02 \pm 3.04^{\mathrm{Aa}}$ \\
\hline \multirow{6}{*}{$(\mathrm{mg} / \mathrm{dL})$} & $\mathrm{G}_{2}$ & $36.18 \pm 4.23^{\text {ВСDа }}$ & $34.08 \pm 3.52^{\mathrm{ABCab}}$ & $31.28 \pm 3.78^{\mathrm{CDb}}$ \\
\hline & G3 & $33.15 \pm 4.36^{\mathrm{Da}}$ & $30.85 \pm 4.32^{\mathrm{Ca}}$ & $25.95 \pm 3.55^{\mathrm{Eb}}$ \\
\hline & G4 & $40.67 \pm 3.95^{\mathrm{Aa}}$ & $37.57 \pm 4.05^{\mathrm{Aab}}$ & $34.07 \pm 4.24^{\mathrm{ABCb}}$ \\
\hline & G5 & $37.47 \pm 4.86^{\mathrm{ABCa}}$ & $35.07 \pm 4.47^{\mathrm{ABab}}$ & $32.17 \pm 3.44^{\mathrm{BCb}}$ \\
\hline & G6 & $34.60 \pm 4.85^{\mathrm{CDa}}$ & $32.20 \pm 4.02^{\mathrm{BCab}}$ & $28.80 \pm 3.62^{\mathrm{DEb}}$ \\
\hline & G0 & $0.98 \pm 0.03^{\mathrm{BCa}}$ & $0.98 \pm 0.04^{\mathrm{Aa}}$ & $0.96 \pm 0.04^{\mathrm{Aa}}$ \\
\hline Creatinine & $\mathrm{G}_{1}$ & $0.96 \pm 0.05^{\mathrm{CDa}}$ & $0.93 \pm 0.07^{\mathrm{BCab}}$ & $0.88 \pm 0.03^{\mathrm{BCb}}$ \\
\hline \multirow{5}{*}{$(\mathrm{mg} / \mathrm{dL})$} & $\mathrm{G}_{2}$ & $1.01 \pm 0.03^{\mathrm{Ba}}$ & $0.96 \pm 0.05^{\mathrm{ABb}}$ & $0.86 \pm 0.05^{\mathrm{CDc}}$ \\
\hline & G3 & $1.07 \pm 0.04^{\mathrm{Aa}}$ & $0.99 \pm 0.05^{\mathrm{Ab}}$ & $0.80 \pm 0.06^{\mathrm{Ec}}$ \\
\hline & G4 & $0.99 \pm 0.05^{\mathrm{BCa}}$ & $0.96 \pm 0.04^{\mathrm{Aba}}$ & $0.92 \pm 0.05^{\mathrm{ABb}}$ \\
\hline & G5 & $0.94 \pm 0.04^{\mathrm{Da}}$ & $0.91 \pm 0.05^{\mathrm{CDab}}$ & $0.88 \pm 0.07^{\mathrm{BCb}}$ \\
\hline & G6 & $0.91 \pm 0.05^{\mathrm{Ea}}$ & $0.87 \pm 0.03^{\mathrm{Db}}$ & $0.82 \pm 0.05^{\mathrm{DEc}}$ \\
\hline
\end{tabular}

Means with different upper case letters $(A, B, C)$ are statistically different $(\mathrm{p}<0.05)$ within control and all other hypercholesterolemic groups

\section{CONCLUSION}

This study demonstrates that the Acacia honey was more effective against hypercholesterolemia than the Citrus honey. Among all the experimental groups, $\mathrm{G}_{3}$ (receiving $30 \mathrm{~g}$ Acacia honey $/ 250 \mathrm{~mL} /$ day) was found to be the best, in confronting the harmful effects of said disease followed by $\mathrm{G}_{6}$ (having $30 \mathrm{~g}$ of Citrus honey/250 mL/ day).
Reduction in the values of total cholesterol, LDL, and triglycerides along with the increase in HDL (good cholesterol) were observed in all the subjects of all groups except the control group, but the group receiving more concentrated honey drink was found to be healthier than the others. Additionally, the consumption of honey drinks aided in reducing the body weight of subjects, which could be caused by decreased feed 
intake. It led to the conclusion that the lower glycemic index of honey and presence of hydrogen peroxide were the main contributing factors in reducing the body weight of subjects. Moreover, the presence of antioxidants especially the flavonoids, in both the honey types, aided in controlling hypercholesterolemia more effectively.

\section{ACKNOWLEDGEMENTS}

I am grateful to the management of Library of Government College University, Faisalabad, Pakistan, for providing me with all the necessary material for writing this research paper.

\section{REFERENCES}

Abdel-Moneim, W.M. \& Ghafeer, H.H. 2007. The potential protective effect of natural honey against cadmium-induced hepatotoxicity and nephrotoxicity. Mansoura Journal of Forensic Medicine and Clinical Toxicology 15(2): 75-98.

Achuba, F.I. \& Nwokogba, C.C. 2015. Effects of honey supplementation on hydrocarbon-induced kidney and liver damage in wistar albino rats. Biokemistri 27(1): 50-55.

Adnan, F., Sadiq, M. \& Jehangir, A. 2011. Anti-hyperlipidemic effect of acacia honey (desi kikar) in cholesterol-diet induced hyperlipidemia in rats. Biomedica 27(13): 62-67.

Afroz, R., Tanvir, E.M., Hossain, M., Gan, S.H., Parvez, M., Islam, A. \& Khalil, M. 2014. Protective effect of Sundarban honey against acetaminophen-induced acute hepatonephrotoxicity in rats. Evidence-Based Complementary and Alternative Medicine 2014: 143782.

Ahmad, R.S., Hussain, M.B., Saeed, F., Waheed, M. \& Tufail, T. 2017. Phytochemistry, metabolism, and ethnomedical scenario of honey: A concurrent review. International Journal of Food Properties 20(sup1): S254-S269.

Ahmed, M., Imtiaz Shafiq, M., Khaleeq, A., Huma, R., Abdul Qadir, M., Khalid, A. \& Samad, A. 2016. Physiochemical, biochemical, minerals content analysis, and antioxidant potential of national and international honeys in Pakistan. Journal of Chemistry 2016: 8072305.

Alagwu, E.A., Okwara, J.E., Nneli, R.O. \& Osim, E.E. 2011. Effect of honey intake on serum cholesterol, triglycerides and lipoprotein levels in albino rats and potential benefits on risks of coronary heart disease. Nigerian Journal of Physiological Sciences 26: 161-165.

Ali, A., Akhtar, N., Khan, B.A., Khan, M.S., Rasul, A., ShahiqUZ-Zaman, Khalid, N., Waseem, K., Mahmood, T. \& Ali, L. 2012. Acacia nilotica: A plant of multipurpose medicinal uses. Journal of Medicinal Plants Research 6(9): 1492-1496.

Alvarez-Suarez, J.M., Gasparrini, M., Forbes-Hernández, T.Y., Mazzoni, L. \& Giampieri, F. 2014. The composition and biological activity of honey: A focus on Manuka honey. Foods 3(3): 420-432.
Annoni, G., Botasso, B.M., Ciaci, D., Donato, M.F. \& Tripodi, A. 1982. Liquid triglycerides (GPO-PAP). Medi Diagnostic Italy. Journal of Clinical Medicine 9: 115.

Ballantyne, C.M., Banach, M., Mancini, G.J., Lepor, N.E., Hanselman, J.C., Zhao, X. \& Leiter, L.A. 2018. Efficacy and safety of bempedoic acid added to ezetimibe in statin-intolerant patients with hypercholesterolemia: A randomized, placebo-controlled study. Atherosclerosis 277: 195-203.

Basuny, A.M., Gaafar, A.M. \& Arafat, S.M. 2009. Tomato lycopene is a natural antioxidant and can alleviate hypercholesterolemia. African Journal of Biotechnology 8: 23.

Benzie, I.F. \& Strain, J.J. 1996. The ferric reducing ability of plasma (FRAP) as a measure of "antioxidant power": The FRAP assay. Analytical Biochemistry 239(1): 70-76.

Chaudhari, S.Y., Ruknuddin, G. \& Prajapati, P. 2016. Ethno medicinal values of citrus genus: A review. Medical Journal of Dr. DY Patil University 9(5): 560.

El-Haskoury, R., Al-Waili, N., Kamoun, Z., Makni, M., Al-Waili, H. \& Lyoussi, B. 2018. Antioxidant activity and protective effect of Carob honey in CCl4-induced kidney and liver injury. Archives of Medical Research 49(5): 306-313.

Fihri, A.F., Al-Waili, N.S., El-Haskoury, R., Bakour, M., Amarti, A., Ansari, M.J. \& Lyoussi, B. 2016. Protective effect of morocco carob honey against lead-induced anemia and hepato-renal toxicity. Cellular Physiology and Biochemistry 39(1): $115-122$

Hajar, R. 2016. Framingham contribution to cardiovascular disease. Heart Views: The Official Journal of the Gulf Heart Association 17(2): 78.

Hussain, M.B., Ahmad, R.S., Arshad, M.U., Imran, A. \& Waheed, M. 2019. Comparative nutritional evaluation of different varieties of unifloral honeys. International Journal of Biosciences 15(2): 513-518.

Isla, M.I., Craig, A., Ordoñez, R., Zampini, C., Sayago, J., Bedascarrasbure, E. \& Maldonado, L. 2011. Physico chemical and bioactive properties of honeys from Northwestern Argentina. LWT-Food Science and Technology 44(9): 1922-1930.

Kıvrak, Ş. \& Kıvrak, İ. 2017. Assessment of phenolic profile of Turkish honeys. International Journal of Food Properties 20(4): 864-876.

Kumari, B., Kumar, P., Keshari, J.R., Kumar, A., Pankaj, S. \& Chaudhary, R.K. 2017. Serum BUN and creatinine estimation in patients of overt hypothyroidism: A case control study. International Journal of Research in Medical Sciences 5(9): 3990-3993.

Laslett, L.J., Alagona, P., Clark, B.A., Drozda, J.P., Saldivar, F., Wilson, S.R. \& Hart, M. 2012. The worldwide environment of cardiovascular disease: Prevalence, diagnosis, therapy, and policy issues: A report from the American College of Cardiology. Journal of the American College of Cardiology 60(25 Supplement): S1-S49.

Majid, M., Younis, M.A., Naveed, A.K., Shah, M.U., Azeem, Z. \& Tirmizi, S.H. 2013. Effects of natural honey on blood 
glucose and lipid profile in young healthy Pakistani males. Journal of Ayub Medical College Abbottabad 25(3-4): 44-47.

McNamara, J.R., Cohn, J.S., Wilson, P.W. \& Schaefer, E.J. 1990. Calculated values for low-density lipoprotein cholesterol in the assessment of lipid abnormalities and coronary disease risk. Clinical Chemistry 36(1): 36-42.

Mendis, S., Puska, P., Norrving, B. \& World Health Organization. 2011. Global Atlas on Cardiovascular Disease Prevention and Control. Geneva: World Health Organization.

Mohammadimanesh, A., Vahidiniya, A.A., Doaei, S., Gholamalizadeh, M., Shahvegharas1, Z., Salehi, I. \& Khosravi, H.M. 2019. The effect of different types of honey on the lipid profile of streptozotocin-induced diabetic rats. Archives of Medical Sciences Atherosclerotic Diseases 4: e113-e118.

Münstedt, K., Hoffmann, S., Hauenschild, A., Bülte, M., von Georgi, R. \& Hackethal, A. 2009. Effect of honey on serum cholesterol and lipid values. Journal of Medicinal Food 12(3): 624-628.

Mussatto, S.I. \& Mancilha, I.M. 2007. Non-digestible oligosaccharides: A review. Carbohydrate Polymers 68(3): 587-597.

Nemoseck, T.M., Carmody, E.G., Furchner-Evanson, A., Gleason, M., Li, A., Potter, H. \& Kern, M. 2011. Honey promotes lower weight gain, adiposity, and triglycerides than sucrose in rats. Nutrition Research 31(1): 55-60.

Rao, P.V., Krishnan, K.T., Salleh, N. \& Gan, S.H. 2016. Biological and therapeutic effects of honey produced by honey bees and stingless bees: A comparative review. Revista Brasileira de Farmacognosia 26(5): 657-664.

Ruiz-Ruiz, J.C., Matus-Basto, A.J., Acereto-Escoffié, P. \& Segura-Campos, M.R. 2017. Antioxidant and antiinflammatory activities of phenolic compounds isolated from Melipona beecheii honey. Food and Agricultural Immunology 28(6): 1424-1437.

Samat, S., Kanyan Enchang, F., Nor Hussein, F. \& Wan Ismail, W.I. 2017. Four-week consumption of Malaysian honey reduces excess weight gain and improves obesity-related parameters in high fat diet induced obese rats. EvidenceBased Complementary and Alternative Medicine 2017: 1342150.
Samat, S., Nor, N.A.M., Hussein, F.N. \& Ismail, W.I.W. 2014. Effects of Gelam and Acacia honey acute administration on some biochemical parameters of Sprague Dawley rats. BMC Complementary and Alternative Medicine 14(1): 146.

Shiroma, E.J. \& Lee, I.M. 2010. Physical activity and cardiovascular health: Lessons learned from epidemiological studies across age, gender, and race/ ethnicity. Circulation 122(7): 743-752.

Singleton, V.L., Orthofer, R. \& Lamuela-Raventós, R.M. 1999. Analysis of total phenols and other oxidation substrates and antioxidants by means of Folin-Ciocalteu reagent. Methods in Enzymology 299: 152-178.

Stockbridge, H., Hardy, R.I. \& Glueck, C.J. 1989. Public cholesterol screening: Motivation for participation, followup outcome, self-knowledge, and coronary heart disease risk factor intervention. The Journal of Laboratory and Clinical Medicine 114(2): 142-151.

Tanvir, E.M., Afroz, R., Chowdhury, M.A.Z., Khalil, M.I., Hossain, M.S., Rahman, M.A. \& Gan, S.H. 2015. Honey has a protective effect against chlorpyrifos-induced toxicity on lipid peroxidation, diagnostic markers and hepatic histoarchitecture. European Journal of Integrative Medicine 7(5): 525-533.

Tiffe, T., Wagner, M., Rücker, V., Morbach, C., Gelbrich, G., Störk, S. \& Heuschmann, P.U. 2017. Control of cardiovascular risk factors and its determinants in the general population-findings from the STAAB cohort study. BMC Cardiovascular Disorders 17(1): 276.

Uchida, K., Satoh, T., Ogura, Y., Yamaga, N. \& Yamada, K. 2001. Effect of partial ileal bypass on cholesterol and bile acid metabolism in rats. Yanago Acta Medica 44: 69-77.

World Health Organization. 2018. Mortality and Global Health Estimates: Causes of Death; Projections for 2015-2030. Projection of death rates.

Department of Food Science

Faculty of Life Sciences

Government College University, Faisalabad

Pakistan

*Corresponding author; email: rabiaahmad@gcuf.edu.pk

Received: 1 November 2020

Accepted: 18 February 2021 